\title{
P72. Transgenic expression of a chimeric signaling receptor to facilitate $T$ cell costimulation in the tumour environment
}

\author{
R Schlenker ${ }^{1 *}$, M Leisegang ${ }^{2}$, W U ckert $^{2}$, E Noessner $^{1}$ \\ From 1st Immunotherapy of Cancer Conference (ITOC1) \\ Munich, Germany. 12-14 March 2014
}

Tumour therapy with $\mathrm{T}$ cell receptor (TCR) engineered $\mathrm{T}$ cells is reported to induce clinical responses but shortcomings regarding poor in vivo persistence and loss of function in the tumour milieu have been observed. Providing costimulation to adoptively transferred $\mathrm{T}$ cells may improve these shortcomings. However, human $\mathrm{T}$ effector cells are largely CD28 negative and epithelial tumours do not express CD80 or CD86. Therefore, costimulation of human CD8 T effector cells cannot be triggered via the classical way of CD28 ligation. We propose to facilitate costimulation of CD8 $\mathrm{T}$ effector cells in the tumour milieu through retroviral engineering of $\mathrm{T}$ cells with a chimeric signaling molecule (CSM). This CSM is consisted of an intracellular costimulatory domain fused to an extracellular domain with binding capacity for a ligand expressed by a great variety of tumours.

Human activated PBL retrovirally transduced to express the CSM exhibited a survival advantage during in vitro expansion according to clinical protocol. The effect of the chimeric molecule on $\mathrm{T}$ cell function was analyzed using $\mathrm{T}$ cells expressing a tumour antigen specific TCR alone or in combination with the CSM. Transduced $\mathrm{T}$ cells were stimulated with target cells positive or negative for the CSM ligand (CSM-L). CSM expressing T cells responded better to CSM- $\mathrm{L}^{+}$target cells showing higher phosphorylation of ERK and RPS6 compared to stimulation with CSM- $\mathrm{L}^{-}$target cells. $\mathrm{CSM}^{-} \mathrm{T}$ cells responded equally to both target cells. Accordingly, $\mathrm{CSM}^{+}$but not CSM${ }^{-} \mathrm{T}$ cells secreted more IL- 2 and IFN- $\gamma$ upon co-culture with CSM- $\mathrm{L}^{+}$target cells. In summary, transduction of PBL with the chimeric signaling

'Helmholtz Zentrum Muenchen, Institute of Molecular Immunology, Munich, Germany

Full list of author information is available at the end of the article molecule supported T cell survival and TCR induced signaling leading to enhanced $\mathrm{T}$ cell function.

\section{Authors' details}

'Helmholtz Zentrum Muenchen, Institute of Molecular Immunology, Munich, Germany. ${ }^{2}$ Max Delbrueck Center for Molecular Medicine, Molecular Cell Biology and Gene Therapy, Berlin, Germany.

Published: 12 March 2014

\section{doi:10.1186/2051-1426-2-S2-P46}

Cite this article as: Schlenker et al:: P72. Transgenic expression of a chimeric signaling receptor to facilitate $T$ cell costimulation in the tumour environment. Journal for ImmunoTherapy of Cancer 2014 2(Suppl 2):P46.

Submit your next manuscript to BioMed Central and take full advantage of:

- Convenient online submission

- Thorough peer review

- No space constraints or color figure charges

- Immediate publication on acceptance

- Inclusion in PubMed, CAS, Scopus and Google Scholar

- Research which is freely available for redistribution 